\title{
Changes in physical, chemical and functional properties of whey protein isolate (WPI) and sugar beet pectin (SBP) conjugates formed by controlled dry-heating
}

\author{
Phoebe X. Qi ${ }^{a, 1}{ }^{*}$, Yingping Xiao ${ }^{a, b, 1}$ and Edward D. Wickham ${ }^{a}$
}

Mention of trade names or commercial products in this publication is solely for the purpose of providing specific information and does not imply recommendation or endorsement by the U.S. Department of Agriculture. USDA is an equal opportunity provider and employer. 


\section{Abstract}

A M aillard type reaction in the dry state was utilized to create conjugates between whey protein isolate (W PI) and sugar beet pectin (SBP) to achieve improved functional properties including solubility, colloidal stability and oil-in-water emulsion stability. To optimize the reaction conditions, mixtures of $\mathrm{WPI}$ and $\mathrm{SBP}$ at varying weight ratios, 3:1, 2:1 and 1:1, were heated at $60{ }^{\circ} \mathrm{C}, 79 \% \mathrm{RH}$ for $72 \mathrm{hrs}$. Changes in the physical properties, i.e solubility, and chemical compositions, i.e. free sulfhydryl and amine contents were assessed using chemical assays. B radford assay results demonstrated that the protein solubility of W PI increased significantly, $20 \%$ by reacting with lower levels of SBP (3:1 and 2:1) whereas the total powder solubility was not affected until an equal ratio of SBP was used, and the reduction was only $\sim 15 \%$. The free sulfhydryl $(\mathrm{SH})$ and primary $\left(\mathrm{NH}_{2}\right)$ and secondary amine $(\mathrm{NH})$ contents of $\mathrm{WPI}$ were al so mitigated by conjugating with SBP. The formation of the covalent conjugates between W PI and SBP was confirmed by SDS-PA GE gel electrophoresis through staining for both proteins and glycoproteins. The UV-VIS spectroscopy showed significant changes in the molecular electronic transition states of both W PI and the feruloyl moieties of SBP upon interaction and conjugation. M easurements of $\zeta$-potential, particles size distribution and average particle size demonstrated that the W PI-SB P conjugates prepared at the weight ratio of 3:1 were most effective at stabilizing oil-in-water emulsions than other ratios used in this work.

K eywords: M aillard reaction; O/W emulsion stability; whey protein isolate; sugar beet pectin; conjugation; UV-V is spectroscopy 


\section{Introduction}

Once a waste product from the cheese manufacturing and an environmental burden, whey proteins have increasingly been recognized as an invaluable food and non-food ingredient for their undeniable health benefits and versatile functional properties. Research in the past few decades has provided a large body of evidence on the numerous physical, chemical, nutritional and biological prominences that the whey protein components sustain (de Wit, 1998; Smithers, 2015). Combined with the fast growing processing and manufacturing technologies, whey proteins have found their way in a diverse and expanding range of food products, including sports beverages, nutritional supplements, infant formula, pharmaceutical formulations, and nonfood such as personal care products. Despite these developments, whey proteins are still excluded by certain formulation conditions and processing operations which prevent their potentials to be fully realized (Cayot \& Lorient, 1997; Foegeding, Davis, Doucet, \& M cGuffey, 2002; Wijayanti, Bansal, \& Deeth, 2014). These impediments include reduced solubility and thermal stability (de Wit \& K essel, 1996; K azmierski \& Corredig, 2003; Pelegrine \& Gasparetto, 2005; Ryan \& Foegeding, 2015), and diminished emulsion stability (D emetriades, Coupland, \& M cClements, 1997; Fachin \& Viotto, 2005; Hunt \& Dalgleish, 1994; M cClements, M onahan, \& K insella, 1993; M oon \& M angino, 2004) caused by protein denaturation, polymerization and aggregation.

These techno-functional issues have led increasing research effort to the M aillard-type reaction to create conjugates between whey proteins and carbohydrates including mono- and polysaccharides (de Oliveira, dos Reis Coimbra, de Oliveira, Zuñiga, \& Garcia Rojas, 2016; Dickinson, 2009, 2015; Evans, Ratcliffe, \& Williams, 2013). U sing this simple modification 
process, progress has been made in improving the emulsifying and gelation properties as well as the thermal stability of the end products. These research results demonstrated that when whey proteins were dry-heated at controlled temperature, relative humidity $(\mathrm{RH})$ and reaction time with appropriate weight ratios of polysaccharide, a significant improvement in the functional properties (e.g. emulsion and gelation) was observed in the conjugated products. These polysaccharides included dextran (A khtar \& Dickinson, 2003; Jiménez-Castaño, Villamiel, \& López-Fandiño, 2007; Shekaripour, A minlari, Niakosari, \& Eskandary, 2014; Spotti, et al., 2014), maltodextrin (A khtar \& Dickinson, 2007; M artinez-A lvarenga, et al., 2014), xanthan gum (B enichou, A serin, Lutz, \& Garti, 2007), carboxymethylcellulose (K ika, K orlos, \& K iosseoglou, 2007; K oupantsis \& K iosseoglou, 2009) and pectin (Einhorn-Stoll, Ulbrich, Sever, \& K unzek, 2005; M ishra, M ann, \& J oshi, 2001; N eirynck, Van der M eeren, B ayarri Gorbe, Dierckx, \& Dewettinck, 2004; Schmidt, et al., 2016; X u, Wang, Jiang, Yuan, \& Gao, 2012).

A by-product of the sugar manufacturing, sugar beet pulp is a rich source of carbohydrates and contains $67-80 \%$ of potentially high valued plant cell wall polysaccharides (Oosterveld, B eldman, Schols, \& Voragen, 1996). N early $19-25 \%$ of these polysaccharides are pectin (Sun \& Hughes, 1999), which is of particular interest to us because creative utilization of sugar beet pulp will increase its economic value over its current primary use as an animal feed. SBP is commonly used as an emulsifier because of its high content of the proteinaceous materials believed to be bound to the side chains through covalent linkages (Evans, et al., 2013; Fishman, Chau, Qi, Hotchkiss, \& Yadav, 2013; Funami, et al., 2007; Leroux, Langendorff, Schick, Vaishnav, \& M azoyer, 2003; Siew \& Williams, 2008; Williams, etal., 2005). Furthermore, SBP is al so rich in feruloyl groups, both as free ferulic acid (Ferreira, Diez, Faulds, 
Soliveri, \& Copa-Patino, 2007; Qi, Chau, Fishman, Wickham, \& Hotchkiss, 2014; Wicker, et al., 2014) and as ester links coval ently attached to the neutral sugar side chains (Guillon \& Thibault, 1990; M icard, Renard, \& Thibault, 1994; O osterveld, B eldman, Schols, \& Voragen, 2000; O osterveld, et al., 1996; Rombouts \& Thibault, 1986). These unique feruloyl groups make SB P an excellent antioxidant and bioactive agent for food and non-food applications ( $G$ raf, 1992; Kikuzaki, Hisamoto, Hirose, A kiyama, \& Taniguchi, 2002; M axwell, B elshaw, \& Waldron, 2012).

Despite these demonstrated attributes of SBP, modifying whey protein using SBP has received little attention, especially through the M aillard-type reaction. To our best knowledge, the only published report (Xu, et al., 2012) involved preparing the whey protein isolate (W PI)SBP conjugates by dry-heating (79\% RH) at varying weight ratios $(20: 1,10: 1,5: 1,2: 1,1: 1$ and 1:2), temperatures $\left(80,90\right.$ and $\left.100^{\circ} \mathrm{C}\right)$ and times $(0$ to $9 \mathrm{hr})$. The resulting products were evaluated in the $\beta$-carotene emulsions stabilization experiments and the conjugates formed at 1:2 ( $80^{\circ} \mathrm{C}$ for $5 \mathrm{hr}$ ) were found to be the most effective in stabilizing the emulsions against freezethaw treatment.

The M aillard reaction involves an initial condensation of a reducing sugar with an amino group of the protein, namely the $\varepsilon$-amino group of the lysine, the $\xi$-amino group of the arginine residues and the $\mathrm{N}$-terminal amino group. A range of reactions takes place subsequently, and leads, via the formation of Schiff base and the A madori rearrangements, to the formation of advanced M aillard reaction products (A M REPs) depending on the nature of the reactants, $\mathrm{pH}$, reaction temperature and time, and humidity (A mes, 1998). It is reported (E inhorn-Stoll, et al., 2005; M ishra, et al., 2001; Schmidt, et al., 2016; Wang \& Ismail, 2012) that the conjugation 
between whey proteins and polysaccharides via the M aillard reaction causes changes in the chemical composition and physical properties such as solubility, protein conformation, and thermal stability. A myriad of the functional properties were greatly improved in polymerized whey protein as a result of these conjugation reactions (K lemaszewski \& K insella, 1991; M onahan, M cClements, \& K insella, 1993). However, a fundamental understanding is still lacking regarding the physical and chemical changes that occurred in the protein as a result of M aillard conjugation with the polysaccharides. Undoubtedly, these changes were responsible for the observed gross improvement in the functional properties.

In addition to conjugating whey proteins and polysaccharides by utilizing the M aillardtype reaction, successful attempts have also been made in forming complexes through noncovalent interactions such as electrostatic, hydrogen binding and hydrophobic interactions under various conditions (A lizadeh-Pasdar, Nakai, \& Li-Chan, 2002; Dickinson, 2008; Evans, et al., 2013; J ones, et al., 2011; M ishra, et al., 2001; Qi, Chau, et al., 2014). When combined, proteins and polysaccharides are expected to form either soluble complexes or coacervates depending on the conditions used (de K ruif, Weinbreck, \& de Vries, 2004; Schmitt \& Turgeon, 2011; Turgeon, B eaulieu, Schmitt, \& Sanchez, 2003; Turgeon, Schmitt, \& Sanchez, 2007).

In this work, we investigate quantitatively the changes that occurred in the physical properties and chemical compositions of whey protein isolate (W PI) conjugated with varying ratios of sugar beet pectin (SBP) through a dry-state M aillard-type reaction, and to correlate these changes with the improved functional properties as observed in the resulting conjugates. Rather than a typical heating time of several weeks, a shortened reaction time was used to limit the reaction propagation and to reduce excessive browning and the formation of possibly 
harmful, toxic and even carcinogenic compounds (de Oliveira, et al., 2016; Ledl \& Schleicher, 1990; Stadler, et al., 2002). 
2. M aterials and $M$ ethods

\subsection{Materials}

All reagents including $\mathrm{NaCl}$, sodium phosphate (monobasic and dibasic), sodium citrate, sodium benzoate, DL-dithiothreitol, 5,5'-dithio-bis-(2-nitrobenzioc acid) (DTNB, Ellman's reagent), $\beta$-mercaptoethanol ( $\geq 99 \%, B M E$ ) and ninhydrin reagent used in these studies, unless otherwise noted, were of the analytical grade or 'A CS certified' from Sigma-A Idrich (St. Louis, M 0). Cold-pressed Valencia orange oil was supplied by Citrus and A pplied Essences Ltd., Belcamp, M D. The Polytron homogenizer (M odel PT 10/35) was purchased from B rinkmann, Westbury, NY and the EmulsiF lex-B 3 high-pressure homogenizer was purchased from Avestin Inc., Ottawa, Canada. Tris UItra Pure was purchased from ICN Biomedicals, Inc. (Cleveland, $\mathrm{OH})$. The electrophoresis reagents including the NuPA GE ${ }^{\circledR}$ Novex ${ }^{\circledR} 12 \%$ Bis-Tris Gels (N P0341), the N uPA GE ${ }^{\circledR}$ LDS Sample Buffer (4X, N P0007), the SimplyBlue ${ }^{\circledR}$ SafeStain (L C6060) and the Pierce ${ }^{\circledR}$ Glycoprotein Staining K it (24562) were supplied by Thermo Fisher Scientific (Waltham, M A). The low molecular weight marker (LM W M) was purchased from GE Healthcare Bio-Sciences Corp. (Piscataway, NJ).

The whey protein isolate (W PI) powder (Provon 190) used in this work was purchased from Glanbia Nutritionals, Inc. (Twin Falls, ID). The components of the spray-dried W PI, according to the manufacturers' specifications are: protein $89.6 \%$; fat $2.5 \%$; moisture $2.8 \%$, and ash 3.3\%.

Sugar beet pectin (SBP, L ot\# 30091) was donated by CP K elco (San Diego, CA ). The composition of the pectin was determined using previously published methods (Qi, Wickham, \& Garcia, 2014; Y 00, Fishman, Savary, \& Hotchkiss, 2003): galacturonic acid (GalA) $58.5 \pm 5.4 \%$; 
degree of methyl esterification (DME), $57.4 \pm 1.0 \%$; degree of acetyl esterification (DAE), 21.7 $\pm 0.1 \%$; and neutral sugar, $37.3 \pm 1.1 \%$. The feruloyl moieties in SBP, bound and free, were estimated to be $0.88 \pm 0.15 \%$ based on the calculations obtained from the UV-VIS spectra of SBP and pure ferulic acid (Qi, Chau, et al., 2014).

2.2. P reparation of WPI-SBP conjugates by dry-heating

The W PI-SB P conjugates were prepared by dry-heating at $60^{\circ} \mathrm{C}$ in a controlled relative humidity (79\%) using saturated $\mathrm{KBr}$ solution for $72 \mathrm{hrs}$, as described separately (Qi, Xiao, \& Wickham, 2017).

2.3. D etermination of the extinction coefficient of sugar beet pectin (SBP) at $325 \mathrm{~nm}$

The extinction coefficient of SBP in $25 \mathrm{mM}$ sodium phosphate (PBS), pH 6.75 was determined by carefully measuring the weight and volume of completely dissolved SB P solution $(\sim 5.0 \mathrm{mg} / \mathrm{mL})$. A fter an overnight stirring at room temperature $\left(20^{\circ} \mathrm{C}\right)$, the solution was centrifuged at $21,400 \times \mathrm{g}$ (also at $20^{\circ} \mathrm{C}$ ) in a Sorvall Legend XTR bench top centrifuge (Thermo Scientific, Germany) for 30 min and a small amount of pellet was discarded. The supernatant was filtered through a 0.45- $\mu$ m syringe-driven filter (M illex HV, PV DF, M illipore Corp., Billerica, M A). The volume ( $\mathrm{V}, \mathrm{mL})$ of the filtered SBP solution was recorded. The UV-VIS spectrum (450-200 nm) (Cary 100 Bio UV-V IS spectrometer, A gilent Technologies, Böblingen, Germany) of the SBP solution were collected, and an absorbance value at $325 \mathrm{~nm}\left(\mathrm{~A}_{325 \mathrm{~nm}}\right)$ was obtained using a quartz cuvette with $0.5-\mathrm{cm}$ path length $(\mathrm{L})$ and the PBS buffer as a reference. The cuvette was then washed $3 \mathrm{x}$ with M illi-Q water. All washes were combined with the SB P 
solution and freeze-dried. A $n$ equal volume (V) of the PBS buffer was also lyophilized to account for the salt contribution from the buffer. The weights of the lyophilized SBP (W SBP, mg) and the buffer salt ( $W_{\text {buffer, }} \mathrm{mg}$ ) were used to calculate the extinction coefficient of SBP at 325 $\mathrm{nm}\left(\varepsilon_{325} \mathrm{~nm}, \mathrm{~mL} \bullet \mathrm{mg}^{-1} \bullet \mathrm{cm}^{-1}\right)$ using the following equation:

$$
\varepsilon_{325}=\frac{A_{325}}{\frac{\left(W_{S B P}-W_{\text {buffer }}\right)}{V} \times L}
$$

2.4. Determination of total powder and protein solubility

Total solubility (\%) of the dry-heated W PI and SBP powder in water was determined by suspending the sample ( $100 \mathrm{mg})$ of known weight $\left(\mathrm{W}_{\mathrm{p}}\right)$ in $\sim 10 \mathrm{~mL}$ M illi-Q water at room temperature for 4-12 hrs. The total weight of the suspension was recorded to be $W_{\text {total }}(\mathrm{mg})$, and centrifuged at $24,000 \times \mathrm{g}$ (also at $20^{\circ} \mathrm{C}$ ) in a Sorvall RC-5B centrifuge (D uPont C 0. , Wilmington, $D E$ ) for 30 min. The supernatant was filtered through a $0.45-\mu \mathrm{m}$ syringe-driven filter (M illex HV, PV DF, M illipore Corp., Billerica, M A ). A fraction of the filtered supernatant with known weight $\left(\mathrm{W}_{\text {Tsol, }} \mathrm{mg}\right)$ was then lyophilized. The weight of the freeze-dried powder is denoted as $\mathrm{W}_{\text {sol, }}$, and the total solubility is calculated as the following:

total solubility $(\%)=\frac{\mathrm{W}_{\text {sol }} / \mathrm{W}_{\text {Tsol }}}{\mathrm{W}_{\mathrm{p}} / \mathrm{W}_{\text {total }}} \times 100$

Protein solubility was determined using a modified B radford method (B asch et al., 1985). $\beta$-LG at varying concentrations, from 0.1 to $1.0 \mathrm{mg} / \mathrm{mL}$, was used to build a standard curve, using $\varepsilon_{280}=0.96 \mathrm{~mL} \bullet \mathrm{mg}^{-1} \bullet \mathrm{cm}^{-1}$ (Townend, Winterbottom, \& Timasheff, 1960). The assay 
solvent contained $0.1 \mathrm{M}$ sodium phosphate, $0.01 \mathrm{M}$ sodium citrate, $50 \mathrm{mM}$ DTT and $4.0 \mathrm{M}$ urea (pH 7.0). The centrifuged and filtered supernatant from the total solubility experiments (described above, $\sim 10 \mathrm{mg} / \mathrm{mL}$ ) was diluted by $10 x$ using the assay solvent. Fifty microliters (50 $\mu \mathrm{L}$ ) of the diluted sample was added to $2.5 \mathrm{~mL}$ prepared dye reagent (according to the directions from the manufacturer). Total protein content in the dry-heated W PI-SB P samples was estimated by taking the sum of total protein in W PI (89.6\%) and in SBP, $4.78 \%$.

All solubility (\%) experiments were repeated three times, and an average and standard deviations were obtained.

It should be pointed that it was reported previously (Alkorta, Llama, \& Serra, 1994) that the presence of pectin (from citrus and apple), at $10 \mathrm{mg} / \mathrm{mL}$, interfered with the determination of protein concentration by B radford assay. The concentration of SB P present in the samples of this work, even at 1:1 ratio, was well below $0.5 \mathrm{mg} / \mathrm{mL}$. Therefore, the interference introduced by SBP was considered negligible.

\subsection{D etermination of soluble sulfhydryl and disulfide bond contents}

Total free sulfhydryl concentration was determined according to the method by Ellman (Ellman, 1959) in combination with a modified procedure provided by the supplier (Sigma, St. L ouis, M O). Twenty milligrams (20 mg) of each dry-heated W PI and SB P sample were dissolved in $1 \mathrm{~mL}$ reaction buffer, which contained $0.1 \mathrm{M}$ sodium phosphate, $8.0 \mathrm{M}$ urea and 1.0 mM EDTA ( $\mathrm{pH}$ 8.0). A fter centrifugation at $18,500 \times \mathrm{xg}$ (at room temperature) for $30 \mathrm{~min}$, the supernatant was filtered through a $0.45-\mu \mathrm{m}$ syringe-driven filter (M illex HV, PV DF, M illipore Corp., Billerica, M A). Two hundred fifty microliters ( $250 \mu \mathrm{L})$ of this sample solution ( $20 \mathrm{mg} /$ 


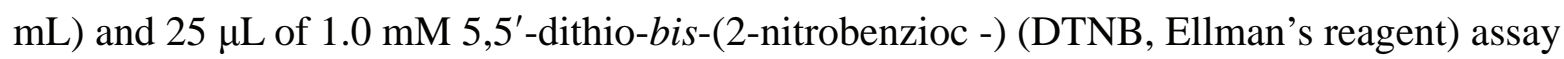
solution were pipetted into $1.125 \mathrm{~mL}$ of the reaction buffer. The reaction mixture was incubated in the dark for $20 \mathrm{~min}$ at room temperature $\left(20^{\circ} \mathrm{C}\right)$, and the absorbance was then recorded at 412 $\mathrm{nm}$ against a blank of $1.125 \mathrm{~mL}$ reaction buffer containing $50 \mu \mathrm{L}$ of $1.0 \mathrm{mM}$ DTNB reagent and $250 \mu \mathrm{L}$ of M illi-Q water. A molar extinction coefficient $\varepsilon_{412}=14,290 \mathrm{M}^{-1} \bullet \mathrm{cm}^{-1}$ for TNB (the colored product from the reaction between -SH and DTNB) (Riddles, B lakeley, \& Zerner, 1983) was used. The final free sulfhydryl concentration $(\mu \mathrm{M})$ was normalized against the total amount of protein $(\mathrm{mg})$ contained in each sample. All assay experiments were performed in triplicate.

\subsection{Determination of soluble primary and secondary amine content}

The Sigma A Idrich product N 7285 ninhydrin reagent solution (2\%) (Starcher, 2001) was used to determine the concentration of the primary and secondary amines in the soluble fraction of the dry-heated W PI samples in the absence and presence of SBP. A stock solution of leucine at concentration of $50 \mathrm{mM}$ in $0.05 \%$ glacial acetic acid was used to prepare the standard curve according to the manufacturer's instructions, and the absorbance was recorded at $570 \mathrm{~nm}$. The concentration of the stock solution for each sample was prepared at $\sim 5.0 \mathrm{mg} / \mathrm{mL}$ in water as described above, in section 2.5. A ppropriate dilutions, 10 to 20 times, were made from the stock solution using $0.05 \%$ glacial acetic acid to obtain reasonable absorbance reading in the range of $0.5-1.0$ at $570 \mathrm{~nm}$ for each assay. The result from the assay yielded concentration of the sum of $\mathrm{NH}$ and $\mathrm{NH}_{2}(\mathrm{mM})$, and was then normalized against the total amount of protein present in each sample as estimated spectrophotometrically (described in section 2.8). 


\subsection{G el electrophoresis}

Sodium dodecyl sulfate-polyacrylamide gel electrophoresis (SDS-PA GE) of all dryheated W PI-SB P samples was carried out using pre-cast mini gels (10 wells), N UPA GE ${ }^{\circledR}$ N ovex ${ }^{\circledR}$ 12\% Bis-Tris Gel (N P0341B OX). The electrophoresis was performed under both native and reducing conditions using $\beta$-mercaptoethanol (BM E, 20\% stock solution). All samples were prepared by dissolving the powder at $2.5 \mathrm{mg} / \mathrm{mL}$ concentration in the diluted ( $4 \mathrm{x}$ with $\mathrm{M}$ illi-Q water) sample buffer NuPA GE ${ }^{\circledR}$ LDS (4X, N P0007). All sample solutions containing $1 X$ sample buffer and BME (50 mg/mL, when used) were first vortexed and then centrifuged at $21,400 \mathrm{xg}$ for $30 \mathrm{~min}$. Ten microliters $(\sim 25.0 \mu \mathrm{g})$ of supernatant from each sample solution were loaded into each well of the gel. The running buffer was N uPA GE ${ }^{\circledR}$ Tris-A cetate SDS R unning Buffer (20X) (LA 0041) and used according to the procedures by the manufacturer. The L M W M was also treated in the absence and presence of BME before use. Gel was stained with SimplyB lue ${ }^{\circledR}$ SafeStain (LC6060) for 3 hrs followed by destaining in a solution containing $30 \%$ methanol and $10 \%$ acetic acid to the desired color density level. For glycoprotein staining, the procedure as recommended by the manufacturer (Thermo Fisher Scientific, Inc.) of the Pierce ${ }^{\circledR}$ Glycoprotein Staining K it (\#24562) was followed using both the positive (horseradish peroxidase) and negative (soybean trypsin inhibitor) controls provided by the supplier.

\subsection{Determination of WPI and SBP concentrations in dry-heated mixtures}

U nless otherwise noted, the stock solutions for the spectroscopic studies in this work including W PI, W PI-dh, SBP, SB P-dh, and dry-heated W PI and SBP mixtures were prepared at a concentration of $5.0 \mathrm{mg} / \mathrm{mL}$ in $25 \mathrm{mM}$ sodium phosphate buffer, $\mathrm{pH}$ 6.75. Each sample was 
stirred in the buffer for a few hours at room temperature $\left(20^{\circ} \mathrm{C}\right)$, and then followed by centrifugation and filtration as described in section 2.3. The UV-VIS spectra $(450-200 \mathrm{~nm})$ of 5 times diluted solutions (in the same buffer) were recorded using a Cary 100 Bio UV-VIS spectrometer (A gilent Technologies, B öblingen, Germany). The absorbance values at 330, 325 and $278 \mathrm{~nm}$ were recorded using a quartz cuvette with $1.0-\mathrm{cm}$ path length $(\mathrm{L})$ and the phosphate buffer as a reference. The concentration of W PI, W PI-dh, SBP and SB P-dh was then calculated based on the B eer- $L$ ambert law: $C=A / \varepsilon L$ using the extinction coefficient $\varepsilon_{278}=1.046$ $\mathrm{mL} \bullet \mathrm{mg}^{-1} \bullet \mathrm{cm}^{-1}$ (M ahmoudi, M ehal ebi, Nicolai, Durand, \& Riaublanc, 2007) and $\varepsilon_{325}=0.763$ $\mathrm{mL} \bullet \mathrm{mg}^{-1} \bullet \mathrm{cm}^{-1}$ (determined in this work, section 2.3.) for W PI and SBP respectively. The absorption at $278 \mathrm{~nm}$ for W PI and W PI-dh was corrected for light scattering $\left(A_{330}>>0.0\right)$ using $\mathrm{A}_{278}($ corrected $)=\mathrm{A}_{278}-1.986 \times \mathrm{A}_{330}($ Grimsley $\&$ Pace, 2004) .

Because of the considerable absorption contribution at $278 \mathrm{~nm}$ by SBP and a much lesser degree at $325 \mathrm{~nm}$ by WPI, the contribution of SBP and WPI to the mixture was estimated by taking the ratios of $\mathrm{A}_{278}$ and $\mathrm{A}_{325}$ for $\mathrm{SBP}$ and $\mathrm{WPI}$ in their respective absorption spectrum in 25 mM phosphate buffer, pH 6.75, to yield $\left(A_{278} / A_{325}\right)^{S B P}$ and $\left(A_{325} / A_{278}\right)^{W P I}$, which are 0.56 and 0.015 respectively. The concentrations of W PI and SBP in each mixture were calculated as the following:

$$
\begin{gathered}
C_{\mathrm{WPI}}=\frac{\mathrm{A}_{278}-\mathrm{A}_{325} \times\left(\mathrm{A}_{278} / \mathrm{A}_{325}\right)^{\mathrm{SBP}}}{\varepsilon_{278}^{\mathrm{WPI}} \times \mathrm{L}} \times \mathrm{DF} \\
C_{\mathrm{SBP}}=\frac{\mathrm{A}_{325}-\mathrm{A}_{278} \times\left(\mathrm{A}_{325} / \mathrm{A}_{278}\right)^{\mathrm{WPI}}}{\varepsilon_{325}^{\mathrm{SBP}} \times \mathrm{L}} \times \mathrm{DF}
\end{gathered}
$$


Where DF stands for dilution factor, and $L(1.0 \mathrm{~cm})$ is the cell path length of the cuvette used in the UV-VIS experiments.

All concentrations $(\mathrm{mg} / \mathrm{mL})$ determined by UV-VIS spectroscopy were repeated three times, and an average and standard deviation were obtained.

\subsection{Electrophoretic mobility measurements}

All samples studied in this work, including W PI, W PI-dh, SBP and their conjugates (3:1, 2:1 and 1:1) were dissolved at $2.0 \mathrm{mg} / \mathrm{ml}$ in $33 \mathrm{mM}$ sodium phosphate buffer $(\mathrm{I}=50 \mathrm{mM}, \mathrm{pH}$ 6.75). Electrophoretic mobility $\left(20^{\circ} \mathrm{C}\right)$ of these solutions was determined by the Zetasizer $\mathrm{N}$ ano Z system ( $M$ alvern Instruments, Worcestershire, U.K.). Samples were inserted in plastic folded capillary cells (M alvern Instruments) possessing two metal electrodes at the capillary ends. The instrument operates by measuring the velocity of the colloidal particles when a pulsed electric field is applied using the Laser Doppler Velocimetry technique. The electrophoretic mobility was measured with a Zetasizer NanoZS (M alvern Instruments). $\zeta$-Potential was converted into millivolts ( $\mathrm{mV}$ ) by the software (v.7.03), also provided by M alvern Instruments.

\subsection{Emulsion preparation}

Emulsions were prepared in a buffer system containing $33 \mathrm{mM}$ sodium phosphate, and $0.1 \%(\mathrm{w} / \mathrm{w}$ ) sodium benzoate (a preservative), $\mathrm{pH} 6.75$. The stock solution of each emulsion was prepared by slowly adding the calculated amount (11.2 mg/g) of W PI, SBP and the dry-heated mixture a little at a time with vigorous stirring to the buffer at room temperature and then gently 
stirring overnight to produce a hydrated, well dissolved and homogeneous solution. The samples for oil-in-water emulsions were prepared in triplicate for each sample at 1:4 for emulsifier to oil weight ratio by taking $9.0 \mathrm{~g}$ of above emul sifier stock solution ( $100 \mathrm{mg}$ adjusted to W PI only according to calculated concentration in Table 1$)$ and $4 \%(400 \mathrm{mg}$ ) of Valencia orange oil to obtain the final total $10.0 \mathrm{~g}$ solution (using the above buffer) in a glass vial. No weighting agent was added during emulsion preparation to avoid the effects of such agent on the emulsification process. The solution was vortexed and then homogenized using a polytron bench top homogenizer equipped with a $12 \mathrm{~mm}$ diameter head (Brinkmann, Switzerland, PT 10/35) at $20,000 \mathrm{rpm}$ for $30 \mathrm{sec}$. The above-homogenized emulsion was then passed through the EmulsiFlex-B3 high-pressure homogenizer (Avestin Inc., Canada) at 20,000 psi homogenization pressure 3 times to yield the final emulsion concentrate. The emulsions were stored at $60^{\circ} \mathrm{C}$ for the duration of the experiment.

\subsection{E mulsion droplet distribution and size measurements}

The oil droplet distribution measurements were made using the same phosphate buffer (pH 6.75) as stated above. The $\mathrm{pH}$ value for each emulsion was recorded to be varying from 6.22 (for 1:1) to 6.68 for W PI controls, which were considered relatively close to the buffer pH. A t a given time interval, the emulsion was mixed and a 100 ?? $\mu \mathrm{L}$ al iquot was dispersed in M illiQ water and used in the funnel of a HORIBA L aser Scattering Particle Size Distribution A nalyzer LA -950 (H oriba Ltd., K yoto, Japan). Particle size distribution calculations were made on the volume basis. Refractory index of the oil and water were kept 1.450 and 1.333 respectively. The emulsifying stability was assessed by the particles poly-dispersion and the 
value of the volume-weighted average droplet diameters. The average droplet size was measured at time 0 (immediately after preparation) and after storage at $60^{\circ} \mathrm{C}$ for 3 and 7 days.

\subsection{Statistical Analysis}

All results were represented as the means of triple measurements. To evaluate the differences among various samples, one-way analysis of variance (A NOVA) was performed using StatPlus software (A nalystSoft, Walnut, CA ). Pairwise comparison between samples was carried out using a two-tailed Student t-test with unequal variance. P values of $<0.05$ were considered statistically significant.

\section{Resultsand Disaussion}

\subsection{Effects of dry-heating and SBP on the solubility of WPI-SBP conjugates}

The total powder and protein solubility of the dry-heated WPI in the absence and presence of varying amount of SBP were assessed by weight difference (Eq. 1) and the B radford assay method respectively. Figure $1 \mathrm{~A}$ compares the results and shows clearly that mild dryheating condition ( $60{ }^{\circ} \mathrm{C}, 79 \% \mathrm{RH}$ and $72 \mathrm{hrs}$ ) decreased the total solubility of W PI by $\sim 5 \%$ compared to the W PI control. SBP was nearly completely soluble under similar experimental conditions (10 mg/mL in water). The $\mathrm{pH}$ of the solution, however, was $\sim 3.5$, making it inappropriate to be compared with all other samples (pH $\sim 6.0$ at the same concentration). Therefore, it was excluded from Fig. 1A. The presence of SB P at lower weight ratios, 3:1 and 2:1, appeared to have negligible effect $(P>0.05)$ on the total solubility of the mixture compared to W PI-dh, when SBP was absent. At an equal amount of SBP (WPI:SBP=1:1), the total solubility of the heated mixture dropped considerably, by $\sim 17 \%$ and $\sim 12 \%$ compared to W PI and 
WPI-dh respectively. This could be caused by the overall limited solubility of SBP in water $(\sim 2 \%)$.

Figure 1B shows the protein solubility of W PI dry-heated at various ratios of SBP. It is clear that the protein solubility was reduced slightly, $\sim 3 \%(\mathrm{P}<0.01)$, by dry-heating alone (W PIdh) due to protein denaturation compared to the control, WPI. Interestingly, the presence of SBP, at lower ratios, 3:1 and 2:1, increased the protein solubility dramatically, by $17 \%$ and $20 \%$ compared to W PI respectively. This can be attributed to the conjugates formed between the protein components of WPI including $\beta-L G, \alpha-L A, I g G$ and BSA and the limiting amount of SBP were more soluble than unreacted W PI. It should be noted that these interactions are only of chemical conjugation in nature because the assay conditions used in this work would disrupt any forms of physical interactions, e.g. electrostatic and hydrophobic interaction. M ore importantly, the molecular structure of WPI, both the secondary and tertiary levels, was significantly stabilized by interacting and conjugating with a lower level of SB P (3:1 and 2:1), as demonstrated in our subsequent spectroscopic studies (Qi, et al., 2017). In addition to the highly soluble and sustainable conjugates formed between WPI and SBP, i.e in the form of FRET, the basic residues ( $\mathrm{Arg}$, Lys and $\mathrm{H}$ is) and the aromatic residues (Phe, Tyr and Trp) of the unreacted WPI appeared to have become more susceptible and accessible to the binding of the Coomasie B rilliant B lue G-250 dye (the B radford assay reagent) than the W PI control. Further research is currently being carried out in our laboratory to provide an in-depth understanding of this remarkable improvement on the solubility of WPI (by SBP).

Increasing SBP to an equal level as W PI (1:1), however, led the protein solubility to drop to a comparable level to that of the dry-heated W PI (W PI-dh). This is anything but surprising. 
First of all, the fraction of soluble protein should be strictly affected by the total powder solubility (Fig. 1A). Secondly, other chemical changes also took place, i.e. loss of free SH and primary amine levels, as a result of the conjugation reactions (discussed below), which would impact negatively on the protein solubility. We proposed two different interaction and reaction schemes (Qi, et al., 2017) for the reactions at higher W PI and SBP ratios (3:1 and 2:1) versus that occurred at an equal level (1:1). Nevertheless, the soluble fraction of WPI was evidently held steady by reacting with SB P despite the heat-induced denaturation effect in this case (1:1), demonstrating the overall positive effect of reacting with SBP on the solubility and stability of WPI at all levels.

The concentrations of W PI and SBP $(\mathrm{mg} / \mathrm{mL}$ ) in the stock solutions (total $\sim 5 \mathrm{mg} / \mathrm{mL}$ in $25 \mathrm{mM}$ phosphate, pH 6.75) were estimated using Eqs. 3 and 4 as described in section 2.8 and are given in Table 1. It should be acknowledged that the source of error in obtaining the concentrations (listed in Table 1) largely resided in the assumption that the extinction coefficients for $\mathrm{WPI}$ and SBP (at $278 \mathrm{~nm}$ and $325 \mathrm{~nm}$ respectively) remained unchanged in the conjugates from their unmodified states. Nevertheless, it is important to obtain an estimation of the concentration of each component in the mixtures using the approximation procedure outline in this work.

\subsection{Effects of dry-heating and SBP on the chemical composition of WPI}

The effect of dry-heating in the absence and presence of SB P on the chemical composition of W PI was studied by DTNB and ninhydrin assay methods respectively (Figure 2). Figures $2 \mathrm{~A}$ and $2 \mathrm{~B}$ show a considerable loss in both free sulfhydryl $(\mathrm{SH})$ and primary $\left(\mathrm{NH}_{2}\right)$ and 
secondary $(\mathrm{NH})$ amine contents (normalized by the total amount of protein present) as a result of dry-heating, in W PI-dh. This is apparently caused by protein denaturation and increased level of disulfide bonds (S-S), both intra- and intermolecular among different proteins in whey, especially involving $\beta-L G$ and $\alpha-L A$ upon heating. The presence of $S B P$, at relatively low weight ratios, 3:1 and 2:1, evidently mitigated the losses of soluble sulfhydryl (SH) and available primary and secondary amines compared to the dry-heated control $(P<0.05)$, W PI-dh. Higher level of SBP (1:1) caused the SH to decrease to the level below that of W PI-dh, indicative of increased protein denaturation and aggregation. B ecause the assay was performed using the soluble fraction of the reacted mixtures, it is therefore not surprising that the effect of SBP on the free $\mathrm{SH}$ content of W PI and conjugates formed with SBP mirrored the protein solubility results (Fig. 1B). On the other hand, the concentration of primary $\left(\mathrm{NH}_{2}\right)$ and secondary $(\mathrm{NH})$ amine of $\mathrm{WPI}$ and conjugates didn't suffer much reduction by an equal weight ratio of SBP. This is consistent with the notion that the level of conjugates formed was limited by the available W PI, as noted above.

The concentrations of $\mathrm{NH}_{2}$ and $\mathrm{NH}$ in W PI were apparently preserved by the presence of all levels of SBP. This observation further attests the protective effect of SBP, particularly at lower ratios, on WPI against heat treatment by forming conjugates either covalently through a M aillard type of reaction. It should be pointed out that the ninhydrin assay method used in this work is not sensitive enough to detect exclusively the reduction in the primary amine level $\left(\mathrm{NH}_{2}\right)$ of WPI caused by the M aillard reaction with SBP, in which case, any remaining (unreacted) $\mathrm{NH}_{2}$ and resulting $\mathrm{NH}$ (of the products) were also included.

The SDS-PA GE electrophoretic profiles of dry-heated W PI at varying ratios of SBP with and without the use of the reducing agent ( $\beta$-mercaptoethanol), stained with Coomassie blue (for 
proteins) are shown in Figures $3 \mathrm{~A}$ and $3 \mathrm{~B}$ respectively. Under non-reducing conditions (Fig. $3 A$ ), all samples, both in the absence ( $L$ ane 2 ) and presence of SBP (Lanes 3, 4 and 5 ) displayed the formation of heat-induced high molecular weight species, i.e aggregates formed among the proteins of W PI and conjugated complexes between W PI and SBP, which were all soluble but too large to migrate into the gel, except for the W PI control (L ane 1). In addition, large molecular weight species within the range of the gel separating capacity were also visible in all heat-treated samples (L anes 2-5). Reduction of the disulfide bonds (S-S) by B M E (Fig. 3B) caused the amount of species with extremely high molecular weight that remained in the stacking gel (Fig. 3A) to decline significantly, especially for W PI-dh (L ane 2 ) and at low level of SB P (3:1, Lane 5). Soluble complexes and conjugates formed at higher ratios of SBP, 1:1 and 2:1 are clearly visible in lanes 3 and 4, suggesting the formation of covalent compounds (between W PI and SBP) of much higher molecular weight.

The SDS-PA GE electrophoretic profiles of dry-heated W PI at varying ratios of SBP with and without the use of the reducing agent ( $\beta$-mercaptoethanol, BM E), stained for glycoproteins, are shown in Figures $4 \mathrm{~A}$ and $4 \mathrm{~B}$ respectively. These gel electrophoretograms clearly showed the formation of high molecular weight species in all samples (lanes 5, 6 and 7) due to conjugation reaction between $\mathrm{WPI}$ and varying ratios of SBP. In addition, a low level of glycoproteins (Fig. 4A ), the faint band in stacking gel, was also detected for W PI and W PI-dh, lanes 1 and 3 respectively. These glycoproteins were likely formed between whey protein and residual minimal level of lactose during the W PI manufacturing process. Similar to the gel stained with Coomassie blue shown in Fig. 3B, reduction with B M E significantly reduced the amount of high molecular weight species (lanes 1 and 3, Fig. 4B) to a nearly undetectable level. The high 
molecular weight glycoproteins resulted from conjugation betw een W PI and SBP through dryheating still remained distinctively visible in lanes 5, 6, and 7 (Fig. 4B) upon reduction.

\subsection{Interactions between WPI and SBP induced by dry-heating probed by UV-VIS}

The UV-VIS absorption spectra (450-200 nm) of the dry-heated mixtures of W PI and SBP with varying weight ratios (3:1, 2:1 and 1:1) along with the control samples, WPI, W PI-dh, SBP, and SBP-dh are shown in Figure 5A. A t constant protein concentration $(0.40 \mathrm{mg} / \mathrm{mL}$, $\sim 16.0 \mu \mathrm{M}$ using assumed average molecular weight of $25 \mathrm{kDa}$ for $\mathrm{WPI}$ ), the intensity of the main WPI absorption band at the region $\sim 280 \mathrm{~nm}$ increased upon heating (W PI-dh), demonstrating further solvent exposure of the aromatic residues, namely, Tyr and Trp. In addition, appreciable light scattering in the range of $300-400 \mathrm{~nm}$ was also observed compared to the unheated control, WPI, due to heat-induced denaturation, aggregation and low level of glycosylation (discussed below).

To assess the effect and degree of chemical conjugation as well as physical interactions between WPI and SBP, the near UV absorption spectra of W PI and SBP in the dry-heated mixture were obtained by subtracting the appropriate amounts of SBP and W PI from that of the mixtures (Table 1) accordingly. The resulting calculated absorption spectra of WPI and SBP (in the mixtures) are shown in Figures $5 B$ and $5 C$ respectively, and compared with the experimental spectra of the controls including the untreated (WPI and SBP) and dry-heated controls, W PI-dh

and SBP-dh, all at an equival ent experimental concentrations, 0.40 and $0.45 \mathrm{mg} / \mathrm{mL}$ for W PI and SBP respectively. The presence of SBP (at all weight ratios used) clearly prevented the aromatic residues (Tyr and Trp) of W PI from becoming further solvent exposed, as in the case of dry- 
heated W PI (W PI-dh). This is evidenced by the nearly identical absorption band intensity (at 280 $\mathrm{nm}$ ) of the calculated W PI in the mixture compared to that of the unheated control, W PI (Fig. 5B). A weak but obvious broad absorption band (relative to W PI) centered around $366 \mathrm{~nm}$ was revealed in the presence of all levels of SBP (Fig. 5B), likely caused by the advanced M aillard reaction end products (A M REPS) between WPI and SBP (Suarez, Rajaram, Oronsky, \& Gawinowicz, 1989).

The interactions between WPI and SBP induced by dry-heating also drastically impacted the near-UV absorption spectrum of SBP as well. Figure $5 \mathrm{C}$ illustrates changes in the absorption behavior of SBP, and shows a strong dependence on the amount of W PI used when the concentration of SB P was kept constant at $0.45 \mathrm{mg} / \mathrm{mL}$. A t relative higher ratios of W PI to SBP used in this work, 3:1 and 2:1, an absorption band at $303 \mathrm{~nm}$ showed prominent intensity, nearly equivalent to that of the main absorption peak of SBP (at $325 \mathrm{~nm}$ ). Furthermore, both this absorption band $(\sim 303 \mathrm{~nm})$ and the shoulder band in the area of 350-400 nm saw reduced intensity as the amount of SBP increased, suggesting decreased level of conjugates at equal weight ratio of WPI:SBP (1:1). Perhaps, the presence of excess level of SBP inhibited the formation of A M REPs. Previous work on the WPI-dextran conjugation (Zhu, Damodaran, \& Lucey, 2008) and the sodium caseinate-maltodextrin conjugates (M orris, Sims, Robertson, \& Furneaux, 2004) appeared to also attribute the absorption band at $303 \mathrm{~nm}$ to the Schiff base, the initial product during the M aillard reaction.

The interactions between W PI and SBP as probed by UV-VIS spectroscopy in this work are expected to be both coval ent (eg. M aillard reacted conjugates) as well as non-covalent in nature including hydrophobic, between aromatic side-chains of the W PI proteins and proteinous 
moieties of SBP, and local electrostatic interactions (Qi, Chau, et al., 2014). Whereas conditions used in all chemical assays (as above) inevitably disrupt most physical and intermittent interactions, spectroscopic techniques such as UV-Vis are capable of detecting interactions of all types. The effect of physical interaction on the UV-V is behavior of W PI and SB P can be analyzed by comparing the UV-V is spectra of simple mixtures (data not shown) at varying weight ratios with that of the controls, WPI and SBP at appropriate concentrations. As demonstrated previously (Qi, Wickham, et al., 2014), the physical interactions between $\beta$-LG, a major whey protein, and SB P caused significant changes for each partner on the molecular level. A $n$ in-depth analysis (Qi, et al., 2017) of the UV-Vis spectra of their simple mixtures showed the Tyr and Trp residues of W PI as well as the ferulic acid moieties of SBP were deeply involved in the interactions. Our results were in agreement with the work published by Chevalier et al. (Chevalier, Chobert, \& Dalgalarrondo, 2002) on $\beta$-L G glycated by various simple sugars using near-UV CD spectroscopy, in which they reported disruption in the environment of aromatic side-chains upon glycation.

\subsection{E ffect of conjugation on the electrophoretic mobility}

The $\xi$-potential $(\mathrm{mV})$ of the samples studied in this work at pH 6.75 is given in Figure 6 . Naturally, SB P exhibited higher colloidal stability than the protein (W PI and W PI-dh). Figure 6 al so showed clearly that the conjugation between W PI and SB P increased the colloidal stability $(P<0.05)$ than unreacted W PI and SBP. This increase was directly proportional to the level of SB P used, and reached the highest at the weight ratio of 2:1 (25\% SBP). Further increase in the level of SBP, to 1:1, failed to result in greater $\xi$-potential values $(P>0.05)$. Despite these 
moderate $\xi$-potential values ( $<30 \mathrm{mV}$ measured using the conditions specified), the colloidal stability was improved significantly by conjugating W PI and SBP compared to that of W PI (unheated and heated). Further research is needed to find the optimal ratios between W PI and SBP that would yield maximum colloidal stability. A mong the conditions explored in this work, the ratio of 2:1 between WPI and SBP appeared to give rise to the most stable colloidal system.

\subsection{0 il-in-water (O/W) emulsion stability}

The average droplet particle diameters in the emulsion systems containing W PI, W PI-dh, SBP and their conjugates at varying ratios, 3:1, 2:1 and 1:1, measured immediately after the emulsions (Day 0 ) and after storage at $60^{\circ} \mathrm{C}$ up to a week at $\sim \mathrm{pH} 6.7$ is presented in Figure 7. The el evated storage temperature $\left(60^{\circ} \mathrm{C}\right)$ instead of room temperature was chosen in order to complete the experiments in a reasonable amount time. The W PI, W PI-dh and SBP showed poor emulsion stability with increasing droplet size as a function of storage time. The dry-heating reacted conjugates at varying $W \mathrm{PI}: \mathrm{SB} P$ ratios, produced emulsion droplets of smaller size at Day 0 in comparison to unconjugated W PI and W PI-dh, but bigger relative to SBP. This is presumably because the levels of WPI used in the conjugation reactions were all in excess (including 1:1), and the denatured W PI would behave in a similar fashion as the W PI control in such an emulsion system. A s time progressed, it is evident that all conjugates yielded much smaller droplets than the proteins or SBP alone, and the droplet diameter was reduced to $\sim 1.0 \mu \mathrm{m}$ for 3:1, and less than $1.5 \mu \mathrm{m}$ for 2:1 and 1:1 samples upon extended storage (7 days). The oil-inwater emulsions under the conditions employed were stabilized by the conjugating systems at all reaction ratios. M oreover, the droplet size continued to decline during the storage period, such 
as the case in the $3: 1$ and 1:1 samples. At the storage temperature $\left(60^{\circ} \mathrm{C}\right)$ and time ( 7 days) used, the unreacted W PI likely experienced an increased level of denaturation, making it more susceptible for further physical interactions with the protein moieties and the feruloyl groups of SBP (Qi, Chau, et al., 2014). In addition, the conjugation reaction between W PI and SB P was al so continuing, contributing to the apparently increasing oil droplet emulsion stability. There was no visible creamy layer separation over the storage period of one week in the emulsions prepared with the conjugates, unlike the emulsions of W PI alone which showed a creamy layer separation in a few days (visual observation). A s suggested by Dickinson (Dickinson, 2009) and Yadav (Yadav, Parris, J ohnston, Onwulata, \& Hicks, 2010) for other polysaccharide-protein conjugates, the improved emulsion stabilizing ability of W PI-SB P conjugates might be due to the increased steric and electrostatic repulsion between the bulky hydrophilic polysaccharide moiety around the tiny oil droplets, which protect them against flocculation and coalescence. It is believed that the notably increased protein solubility in 3:1 and 2:1, assessed in this work, played an important role in their increased emulsion stability. To further understand this apparent improved O/W emulsion stability by the W PI-SB P conjugates compared to the unreacted W PI and SBP, we have carried out systematic spectroscopic studies. Results were published in another manuscript (Qi, etal., 2017) in which a mutual stabilization effect was observed for both WPI and SBP in the conjugating and interacting systems formed at ratios of 3:1 and 2:1.

\section{Condusions}

It has been shown in this work that whey protein isolate (W PI) reacts and interacts with varying weight ratios of sugar beet pectin (SBP) through controlled dry-heating $\left(60^{\circ} \mathrm{C}, 79 \%\right.$ 
$\mathrm{RH})$. These interactions are expected to be both covalent, through a $\mathrm{M}$ aillard-type reaction, and non-covalent, local hydrophobic and electrostatic in nature. Protein solubility was increased by nearly $20 \%$ at lower ratios of SBP, 3:1 and 2:1 as a result of the conjugation reaction, whereas the total powder solubility showed little effect by SBP at less than 25\% (3:1). Similarly, reacting with SBP also mitigated changes in the chemical composition of W PI, including free sulfhydryl content and available primary and secondary amine level. The UV-VIS spectroscopy revealed the presence of interacting complexes between WPI and SBP involving the aromatic side-chains of WPI and the feruloyl groups of SBP. These findings established a fundamental understanding on changes in the chemical composition and molecular electronic transition state in W PI caused by interacting and reacting with SBP. Significant improvement in colloidal stability and oil-inwater (O/W) emulsions was observed in the conjugates, especially at the 3:1 ratio, compared to the controls as well as other ratios used in this work. Further research using various spectroscopic techniques has been conducted to shed light on the roles of WPI and SBP in these observed improvements in solubility and emulsion stability. Results have been published (Qi, et al., 2017) separately .

\section{Acknowledgements}

The authors would like to acknowledge Dr. M adhav P. Yadav and M s. Stefanie Simon of USDA-ARS-ERRC for their technical assistance in the emulsion preparation and the subsequent particle size measurements. 


\section{Figure Captions}

Figure 1. A) Total powder solubility (\%); and B) protein solubility (\%) of dry-heated W PI and SBP mixtures in M illi-Q water and room temperature $\left(20^{\circ} \mathrm{C}\right)$ as determined by weight difference and B radford assay methods respectively.

Figure 2. A) Free sulfhydryl content (SH) ( $\mu \mathrm{M}$ per mg protein); and B) the total concentration of primary and secondary amine ( $\mathrm{NH}$ and $\mathrm{NH}_{2}$ ) (mM per mg protein) of dry-heated WPI in the absence and presence of SBP at varying weight ratios as determined by the DTNB and ninhydrin methods respectively. All data were collected in triplicate with standard deviations plotted.

Figure 3. SDS-PA GE analyses of dry-heated WPI and SBP mixtures. Gels were stained with coomassai blue (SimplyB lue ${ }^{\circledR}$ SafeStain). The gels were run at A) non-reducing, and B) reducing (with 5\% B M E) conditions respectively. Samples were loaded in the lanes as the following: 1) WPI; 2) WPI-dh; 3) WPI:SBP = 1:1; 4) WPI:SBP = 2:1; and 5) WPI:SBP = 3:1. The total amount of protein loaded in each lane was estimated to be $\sim 25 \mu \mathrm{g}$.

Figure 4. SDS-PA GE analyses of dry-heated WPI and SBP mixtures. Gels were stained for glycoproteins using the Glycoprotein Staining K it (Thermo Fisher Scientific, Inc.). The gels were run at A) non-reducing, and B) reducing (with 5\% BM E) conditions respectively. Samples were loaded in the lanes as the following: 1) W PI; 2) SBP; 3) W PI-dh; 4) SBP-dh; 5) WPI:SBP = 
$3: 1 ; 6) \mathrm{WPI}: \mathrm{SBP}=2: 1$; and 7) W PI:SBP = 1:1. Both " + " (horseradish peroxidase) and “-" (soybean trypsin inhibitor) controls were also included.

Figure 5. A) UV-VIS spectra of dry-heated W PI and SBP mixtures in 25 mM phosphate buffer, $\mathrm{pH}$ 6.75. The concentration of WPI was kept at $0.40 \mathrm{mg} / \mathrm{mL}$ in all solutions, and the concentrations of SBP were calculated accordingly based on Table 1. The concentration of SBP and SB P-dh was $0.45 \mathrm{mg} / \mathrm{mL}$. B) Calculated UV-VIS spectra of W PI (at $0.40 \mathrm{mg} / \mathrm{mL}$ ) by subtracting the appropriate level of SB P from each mixture. The experimental spectra of W PI and W PI-dh were also plotted as a comparison. C) Calculated UV-VIS spectra of SB P (fixed at $0.45 \mathrm{mg} / \mathrm{mL}$ ) by subtracting the varying amount of W PI from each mixture according to Table 1 . The experimental spectra of SB P and SB P-dh were compared (in solid and dotted grey lines).

Figure 6. $\zeta$-Potentials (mV) of W PI, SBP and the M aillard reacted products $(2.0 \mathrm{mg} / \mathrm{mL}$ in 33 $\mathrm{mM}$ phosphate buffer) at $20^{\circ} \mathrm{C}$. E rror bar represents standard deviation (SDV) of a set of four repeated measurements.

Figure 7. Comparison of the volume-weighted average droplet diameter of emulsions composed of $4 \%$ orange oil and $1 \%$ emulsifier $(\mathrm{w} / \mathrm{w}$ ) in $33 \mathrm{mM}$ sodium phosphate and $0.1 \%$ sodium benzoate buffer, $\sim p H$ 6.3. The emulsifiers used are the following: WPI, WPI-dh, SBP, and the conjugates at 3:1, 2:1 and 1:1. The measurements were taken immediately after making emulsions (Day 0), after storage at $60{ }^{\circ} \mathrm{C}$ for 3 and 7 days. Data are an average of three trials \pm standard deviation. 


\section{REFERENCES}

A khtar, M ., \& Dickinson, E. (2003). Emulsifying properties of whey protein-dextran conjugates at low pH and different salt concentrations. Colloids and Surfaces B: Biointerfaces, 31(1-4), 125-132.

A khtar, M ., \& Dickinson, E. (2007). Whey protein-maltodextrin conjugates as emulsifying agents: A $n$ al ternative to gum arabic. F ood H ydrocolloids, 21(4), 607-616.

A lizadeh-Pasdar, N., Nakai, S., \& Li-Chan, E. C. (2002). Principal component similarity analysis of Raman spectra to study the effects of $\mathrm{pH}$, heating, and $\mathrm{\kappa}$-carrageenan on whey protein structure. J ournal of Agricultural and F ood Chemistry, 50(21), 6042-6052.

A lkorta, I., Llama, M. J., \& Serra, J. L. (1994). Interference by pectin in protein determination. F ood Science and Technology-Lebensmittel-Wissenschaft \& Technologie, 27(1), 39-41.

A mes, J. M . (1998). A pplications of the M aillard reaction in the food industry. F ood Chemistry, 62(4), 431-439.

B enichou, A ., A serin, A ., L utz, R ., \& Garti, N. (2007). Formation and characterization of amphiphilic conjugates of whey protein isolate (W PI)/xanthan to improve surface activity. F ood Hydrocolloids, 21(3), 379-391.

Cayot, P., \& L orient, D. (1997). Structure-Function Relationships of Whey Proteins. In: Damodaran, S. \& Paraf, A. (Eds.), F ood Proteins and Their Applications, Volume 80 of F ood Science and Technology (Vol. 80, pp. 225-256). New York, NY: M arcel Dekker, Inc.

Chevalier, F., Chobert, J.-M ., \& Dalgalarrondo, M . (2002). M aillard glycation of $\beta$-lactoglobulin induces conformation changes. F ood / Nahrung, 46(2), 58-63. 
de K ruif, C. G., Weinbreck, F., \& de Vries, R. (2004). Complex coacervation of proteins and anionic polysaccharides. Current Opinion in Colloid \& Interface Science, 9(5), 340-349. de Oliveira, F. C., dos Reis Coimbra, J. S., de Oliveira, E. B., Zuñiga, A. D. G., \& Garcia Rojas, E. E. (2016). Food protein-polysaccharide conjugates obtained via the M aillard reaction: A review. Critical Reviews in Food Science and Nutrition, 56(7), 1108-1125.

de Wit, J. N . (1998). M arschall Rhone-Poulenc Award L ecture. Nutritional and functional characteristics of whey proteins in food products. J ournal of Dairy Science, 81(3), 597-608. de Wit, J. N., \& K essel, T. (1996). Effects of ionic strength on the solubility of whey protein products. A colloid chemical approach. Food Hydrocolloids, 10(2), 143-149.

Demetriades, K., Coupland, J. N., \& M cClements, D. J. (1997). Physical properties of whey protein stabilized emulsions as related to $\mathrm{pH}$ and $\mathrm{NaCl}$. J ournal of Food Science, 62(2), 342-347.

Dickinson, E. (2008). Interfacial structure and stability of food emulsions as affected by proteinpolysaccharide interactions. Soft Matter, 4(5), 932-942.

Dickinson, E. (2009). Hydrocolloids as emulsifiers and emulsion stabilizers. Food Hydrocolloids, 23(6), 1473-1482.

Dickinson, E. (2015). Colloids in Food: Ingredients, Structure, and Stability. Annual Review of Food Science and Technology, 6(1), 211-233.

Einhorn-Stoll, U., U lbrich, M., Sever, S., \& K unzek, H. (2005). Formation of milk protein-pectin conjugates with improved emulsifying properties by controlled dry heating. Food Hydrocolloids, 19(2), 329-340. 
Ellman, G. L. (1959). Tissue sulfhydryl groups. Archives of Biochemistry and Biophysics, 82(1), 70-77.

Evans, M ., Ratcliffe, I., \& Williams, P. A . (2013). E mulsion stabilisation using polysaccharideprotein complexes. Current 0 pinion in Colloid \& Interface Science, 18, 272-282.

Fachin, L., \& Viotto, W. H. (2005). Effect of pH and heat treatment of cheese whey on solubility and emulsifying properties of whey protein concentrate produced by ultrafiltration. International Dairy J ournal, 15(4), 325-332.

Ferreira, P., Diez, N., Faulds, C. B., Soliveri, J., \& Copa-Patino, J. L. (2007). Release of ferulic acid and feruloylated oligosaccharides from sugar beet pulp by Streptomyces tendae. Bioresource Technology, 98(8), 1522-1528.

Fishman, M. L., Chau, H. K., Qi, P. X., Hotchkiss, A. T., Jr., \& Yadav, M . P. (2013). Physicochemical characterization of protein-associated polysaccharides extracted from sugar beet pulp. Carbohydrate Polymers, 92(2), 2257-2266.

Foegeding, E. A ., Davis, J. P., D oucet, D., \& M cGuffey, M . K . (2002). A dvances in modifying and understanding whey protein functionality. Trends in F ood Science \& Technology, 13(5), 151-159.

Funami, T., Zhang, G., Hiroe, M ., N oda, S., Nakauma, M ., A sai, I., Cowman, M . K., A I-A ssaf, S., \& Phillips, G. O. (2007). Effects of the proteinaceous moiety on the emulsifying properties of sugar beet pectin. F ood Hydrocolloids, 21(8), 1319-1329.

Graf, E. (1992). A ntioxidant potential of ferulic acid. F ree Radical Biology and M edicine, 13(4), 435-448. 
Grimsley, G. R., \& Pace, C. N. (2004). Spectrophotometric determination of protein concentration. Current Protocols in Protein Science, 3.1.1-3.1.9.

Guillon, F., \& Thibault, J.-F. (1990). Oxidative cross-linking of chemically and enzymatically modified sugar-beet pectin. Carbohydrate Polymers, 12(4), 353-374.

H unt, J. A ., \& Dalgleish, D. G. (1994). Effect of pH on the stability and surface composition of emulsions made with whey protein isolate. J ournal of Agricultural and F ood Chemistry, 42(10), 2131-2135.

Jiménez-Castaño, L., Villamiel, M ., \& López-Fandiño, R. (2007). Glycosylation of individual whey proteins by M aillard reaction using dextran of different molecular mass. F ood Hydrocolloids, 21(3), 433-443.

J ones, O. G., Handschin, S., A damcik, J., Harnau, L., B olisetty, S., \& M ezzenga, R. (2011). Complexation of $\beta$-lactoglobulin fibrils and sulfated polysaccharides. Biomacromolecules, 12(8), 3056-3065.

K azmierski, M ., \& Corredig, M . (2003). Characterization of soluble aggregates from whey protein isolate. F ood Hydrocolloids, 17(5), 685-692.

Kika, K., K orlos, F., \& Kiosseoglou, V. (2007). Improvement, by dry-heating, of the emulsionstabilizing properties of a whey protein concentrate obtained through carboxymethylcellulose complexation. F ood Chemistry, 104(3), 1153-1159.

Kikuzaki, H., Hisamoto, M ., Hirose, K ., A kiyama, K ., \& Taniguchi, H. (2002). A ntioxidant properties of ferulic acid and its related compounds. J ournal of Agricultural and F ood Chemistry, 50(7), 2161-2168. 
K lemaszewski, J. L., \& Kinsella, J. E. (1991). Sulfitolysis of whey proteins: effects on emulsion properties. J ournal of Agricultural and F ood Chemistry, 39(6), 1033-1036.

K oupantsis, T., \& K iosseoglou, V. (2009). Whey protein-carboxymethylcellulose interaction in solution and in oil-in-water emulsion systems. Effect on emulsion stability. F ood Hydrocolloids, 23(4), 1156-1163.

Ledl, F., \& Schleicher, E. (1990). N ew aspects of the M aillard reaction in foods and in the human body. Angewandte Chemie International E dition in English, 29(6), 565-594.

Leroux, J., Langendorff, V., Schick, G., Vaishnav, V., \& M azoyer, J. (2003). Emulsion stabilizing properties of pectin. Food Hydrocolloids, 17(4), 455-462.

M ahmoudi, N., M ehalebi, S., Nicolai, T., D urand, D., \& Riaublanc, A . (2007). Light-scattering study of the structure of aggregates and gels formed by heat-denatured whey protein isolate and $\beta$-lactoglobulin at neutral pH. J ournal of Agricultural and F ood Chemistry, 55(8), 3104-3111.

M artinez-A lvarenga, M. S., M artinez-Rodriguez, E. Y., Garcia-A mezquita, L. E., Olivas, G. I., Zamudio-Flores, P. B., A costa-M uniz, C. H., \& Sepulveda, D. R. (2014). Effect of M aillard reaction conditions on the degree of glycation and functional properties of whey protein isolate- maltodextrin conjugates. F ood H ydrocolloids, 38, 110-118.

M axwell, E. G., B elshaw, N. J., \& Waldron, K. W. (2012). Pectin - A n emerging new bioactive food polysaccharide. Trends in F ood Science \& Technology, 24, 64-73.

M cClements, D. J., M onahan, F. J ., \& K insella, J. E. (1993). Disulfide bond formation affects stability of whey-protein isolate emulsions. J ournal of F ood Science, 58(5), 1036-1039. 
M icard, V., Renard, C. M. G. C., \& Thibault, J. F. (1994). Studies on enzymic rel ease of ferulic acid from sugar-beet pulp. LWT - F ood Science and Technology, 27(1), 59-66.

M ishra, S., M ann, B ., \& J oshi, V. K. (2001). Functional improvement of whey protein concentrate on interaction with pectin. F ood Hydrocolloids, 15(1), 9-15.

M onahan, F. J., M cClements, D. J ., \& Kinsella, J. E. (1993). Polymerization of whey proteins in whey protein-stabilized emulsions. J ournal of Agricultural and F ood Chemistry, 41(11), 1826-1829.

M oon, B. K ., \& M angino, M . E. (2004). The effect of preheating on solubility and emulsion stability of whey protein concentrates. M ilchwissenschaft-M ilk Science International, 59(3-4), 165-169.

M orris, G. A ., Sims, I. M ., Robertson, A . J ., \& Furneaux, R. H. (2004). Investigation into the physical and chemical properties of sodium caseinate-maltodextrin glyco-conjugates. F ood Hydrocolloids, 18(6), 1007-1014.

N eirynck, N., Van der M eeren, P., B ayarri Gorbe, S., Dierckx, S., \& Dewettinck, K. (2004). Improved emulsion stabilizing properties of whey protein isolate by conjugation with pectins. F ood H ydrocolloids, 18(6), 949-957.

O osterveld, A., B eldman, G., Schols, H. A ., \& Voragen, A . G. (2000). Characterization of arabinose and ferulic acid rich pectic polysaccharides and hemicelluloses from sugar beet pulp. Carbohydrate Research, 328(2), 185-197.

Oosterveld, A ., B eldman, G., Schols, H. A ., \& Voragen, A . G. J. (1996). A rabinose and ferulic acid rich pectic polysaccharides extracted from sugar beet pulp. Carbohydrate Research, 288(0), 143-153. 
Pelegrine, D. H. G., \& Gasparetto, C. A . (2005). Whey proteins solubility as function of temperature and pH. LWT - F ood Science and Technology, 38(1), 77-80.

Qi, P. X., Chau, H. K., Fishman, M . L., Wickham, E. D., \& Hotchkiss, A. T., J r. (2014). Investigation of molecular interactions between $\beta$-lactoglobulin and sugar beet pectin by multi-detection HPSEC. Carbohydrate Polymers, 107(17), 198-208.

Qi, P. X., Wickham, E. D., \& Garcia, R. A . (2014). Structural and thermal stability of $\beta$ lactoglobulin as a result of interacting with sugar beet pectin. J ournal of Agricultural and F ood Chemistry, 62(30), 7567-7576.

Qi, P. X., Xiao, Y., \& Wickham, E. D. (2017). Stabilization of whey protein isolate (W PI) through interactions with sugar beet pectin (SBP) induced by controlled dry-heating. F ood Hydrocolloids, 67, 1-13.

Riddles, P. W., Blakeley, R. L., \& Zerner, B. (1983). [8] Reassessment of Ellman's Reagent. Methods in Enzymology, 91(Part 1), 49-60.

Rombouts, F. M., \& Thibault, J.-F. (1986). Feruloylated pectic substances from sugar-beet pulp. Carbohydrate Research, 154(1), 177-187.

Ryan, K. N., \& Foegeding, E. A . (2015). Formation of soluble whey protein aggregates and their stability in beverages. F ood Hydrocolloids, 43, 265-274.

Schmidt, U. S., Pietsch, V. L., Rentschler, C., Kurz, T., Endress, H. U., \& Schuchmann, H. P. (2016). Influence of the degree of esterification on the emulsifying performance of conjugates formed between whey protein isolate and citrus pectin. F ood Hydrocolloids, 56, $1-8$. 
Schmitt, C., \& Turgeon, S. L. (2011). Protein/polysaccharide complexes and coacervates in food systems. Advances in Colloid and Interface Science, 167(1-2), 63-70.

Shekaripour, F., A minlari, M ., Niakosari, M ., \& Eskandary, M . H. (2014). Effect of M aillardbased conjugation with dextran on the functional properties of whey protein. Innovation in F ood Science and Technology, 5(4), 1-8.

Siew, C. K., \& Williams, P. A. (2008). Role of protein and ferulic acid in the emulsification properties of sugar beet pectin. J ournal of Agricultural and F ood Chemistry, 56(11), $4164-4171$.

Smithers, G. W. (2015). Whey-ing up the options-Yesterday, today and tomorrow. International Dairy J ournal, 48, 2-14.

Spotti, M. J., M artinez, M. J., Pilosof, A. M. R., Candioti, M. C., Rubiolo, A . C., \& Carrara, C. R. (2014). Influence of M aillard conjugation on structural characteristics and rheological properties of whey protein/dextran systems. F ood Hydrocolloids, 39, 223-230.

Stadler, R. H., Blank, I., Varga, N., Robert, F., Hau, J., Guy, P. A ., Robert, M .-C., \& Riediker, S. (2002). Food chemistry: A crylamide from M aillard reaction products. Nature, 419(6906), $449-450$.

Starcher, B. (2001). A ninhydrin-based assay to quantitate the total protein content of tissue samples. Analytical Biochemistry, 292(1), 125-129.

Suarez, G., Rajaram, R., Oronsky, A . L., \& Gawinowicz, M . A . (1989). N onenzymatic glycation of bovine serum albumin by fructose (fructation). Comparison with the M aillard reaction initiated by glucose. J ournal of Biological Chemistry, 264(24), 3674-3679. 
Sun, R. C., \& Hughes, S. (1999). Fractional isolation and physico-chemical characterization of alkali-soluble polysaccharides from sugar beet pulp. Carbohydrate Polymers, 38(3), 273-281.

Townend, R., Winterbottom, R. J., \& Timasheff, S. N. (1960). M olecular interactions in $\beta$ lactoglobulin. II. UItracentrifugal and electrophoretic studies of the association of $\beta$ lactoglobulin below its isoelectric point. J ournal of the American Chemical Society, 82(12), 3161-3168.

Turgeon, S. L., B eaulieu, M ., Schmitt, C., \& Sanchez, C. (2003). Protein-polysaccharide interactions: phase-ordering kinetics, thermodynamic and structural aspects. Current Opinion in Colloid \& Interface Science, 8(4-5), 401-414.

Turgeon, S. L., Schmitt, C., \& Sanchez, C. (2007). Protein-polysaccharide complexes and coacervates. Current 0 pinion in Colloid \& Interface Science, 12(4-5), 166-178.

Wang, Q., \& Ismail, B. (2012). Effect of M aillard-induced glycosylation on the nutritional quality, solubility, thermal stability and molecular configuration of whey proteinv. International Dairy J ournal, 25(2), 112-122.

Wicker, L., K im, Y., K im, M .- ., Thirkield, B ., Lin, Z., \& J ung, J. (2014). Pectin as a bioactive polysaccharide - Extracting tailored function from less. F ood Hydrocolloids, 42(Part 2), 251-259.

Wijayanti, H. B ., B ansal, N ., \& Deeth, H. C. (2014). Stability of whey proteins during thermal processing: A review. Comprehensive Reviews in F ood Science and F ood Safety, 13(6), $1235-1251$. 
Williams, P. A ., Sayers, C., Viebke, C., Senan, C., M azoyer, J., \& B oulenguer, P. (2005).

Elucidation of the emulsification properties of sugar beet pectin. J ournal of Agricultural and F ood Chemistry, 53(9), 3592-3597.

X u, D., Wang, X., Jiang, J., Yuan, F., \& Gao, Y. (2012). Impact of whey protein-beet pectin conjugation on the physicochemical stability of $\beta$-carotene emulsions. F ood Hydrocolloids, 28(2), 258-266.

Yadav, M. P., Parris, N., J ohnston, D. B., Onwulata, C. I., \& Hicks, K. B. (2010). Corn fiber gum and milk protein conjugates with improved emulsion stability. Carbohydrate Polymers, 81(2), 476-483.

Yoo, S. H., Fishman, M. L., Savary, B. J., \& Hotchkiss, A. T., Jr. (2003). M onovalent saltinduced gelation of enzymatically deesterified pectin. J ournal of Agricultural and F ood Chemistry, 51(25), 7410-7417.

Zhu, D., Damodaran, S., \& L ucey, J. A . (2008). Formation of whey protein isolate (W PI) Dextran conjugates in aqueous solutions. J ournal of Agricultural and F ood Chemistry, 56(16), 7113-7118.

Table 1. Average concentrations $(\mathrm{mg} / \mathrm{mL}$ ) of W PI and SBP in the stock solutions (at $5.0 \mathrm{mg} / \mathrm{mL}$ in 25 mM PBS buffer, pH 6.75) as described in section 2.8 and estimated spectrophotometrically using Eqs. 3 and 4. Results were obtained from triplicate measurements*. 


\begin{tabular}{lcc}
\hline & WPI & SBP \\
\hline WPI & $4.06 \pm 0.06^{a}$ & - \\
WPI-dh & $3.53 \pm 0.08^{b}$ & - \\
SBP & - & $4.91 \pm 0.09^{a}$ \\
SBP-dh & - & $4.68 \pm 0.08^{b}$ \\
WPI:SBP=3:1 & $3.63 \pm 0.05^{\mathrm{b}}$ & $1.23 \pm 0.03^{c}$ \\
WPI:SBP=2:1 & $3.24 \pm 0.07^{c}$ & $1.55 \pm 0.05^{d}$ \\
WPI:SBP=1:1 & $2.24 \pm 0.10^{d}$ & $2.63 \pm 0.03^{\mathrm{d}}$
\end{tabular}

*D ata not sharing the same superscript letter were significantly different $(P<0.05)$ within the same category (W PI and SBP). 
Figure 1.

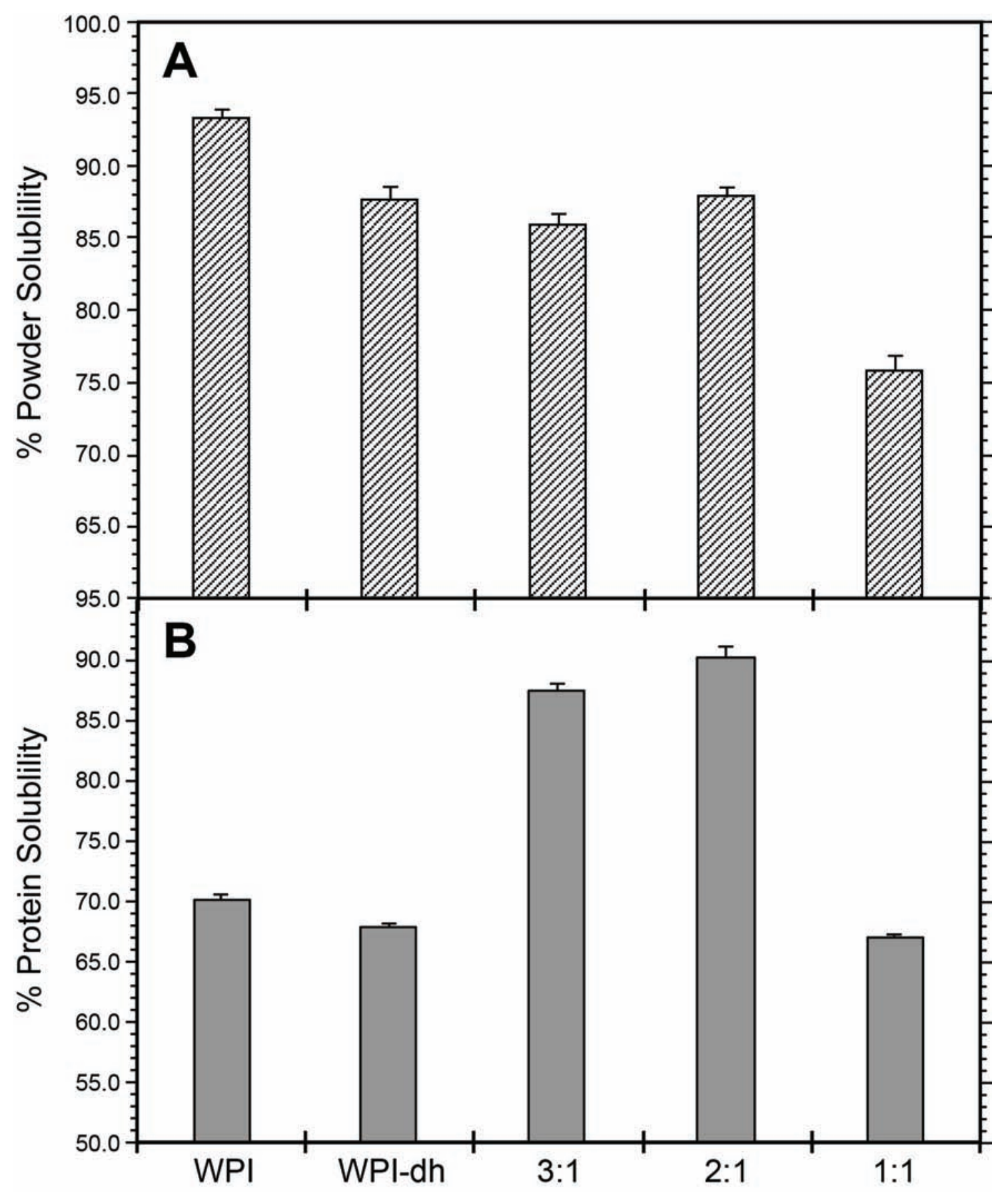


Figure 2.

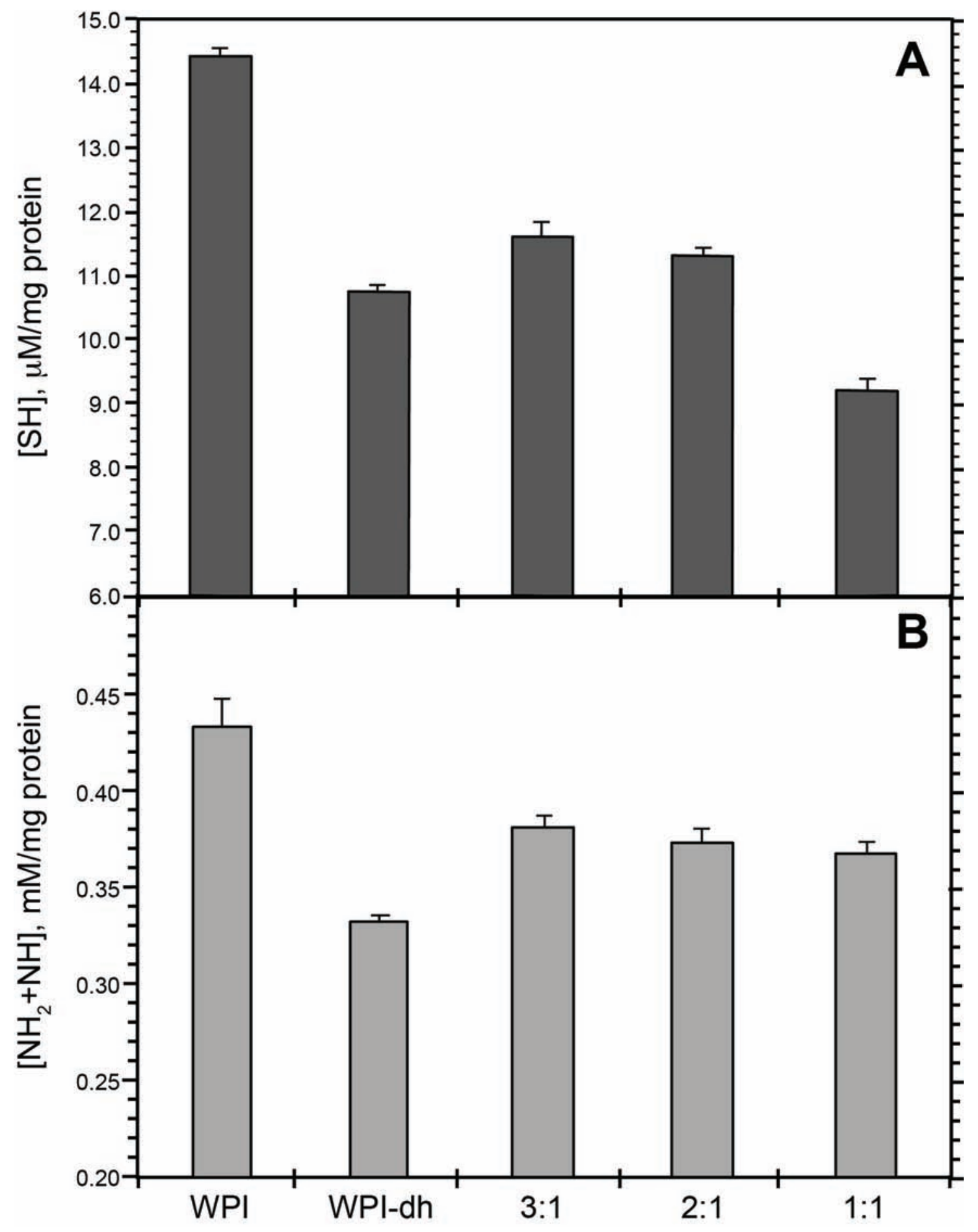


Figure 3A.

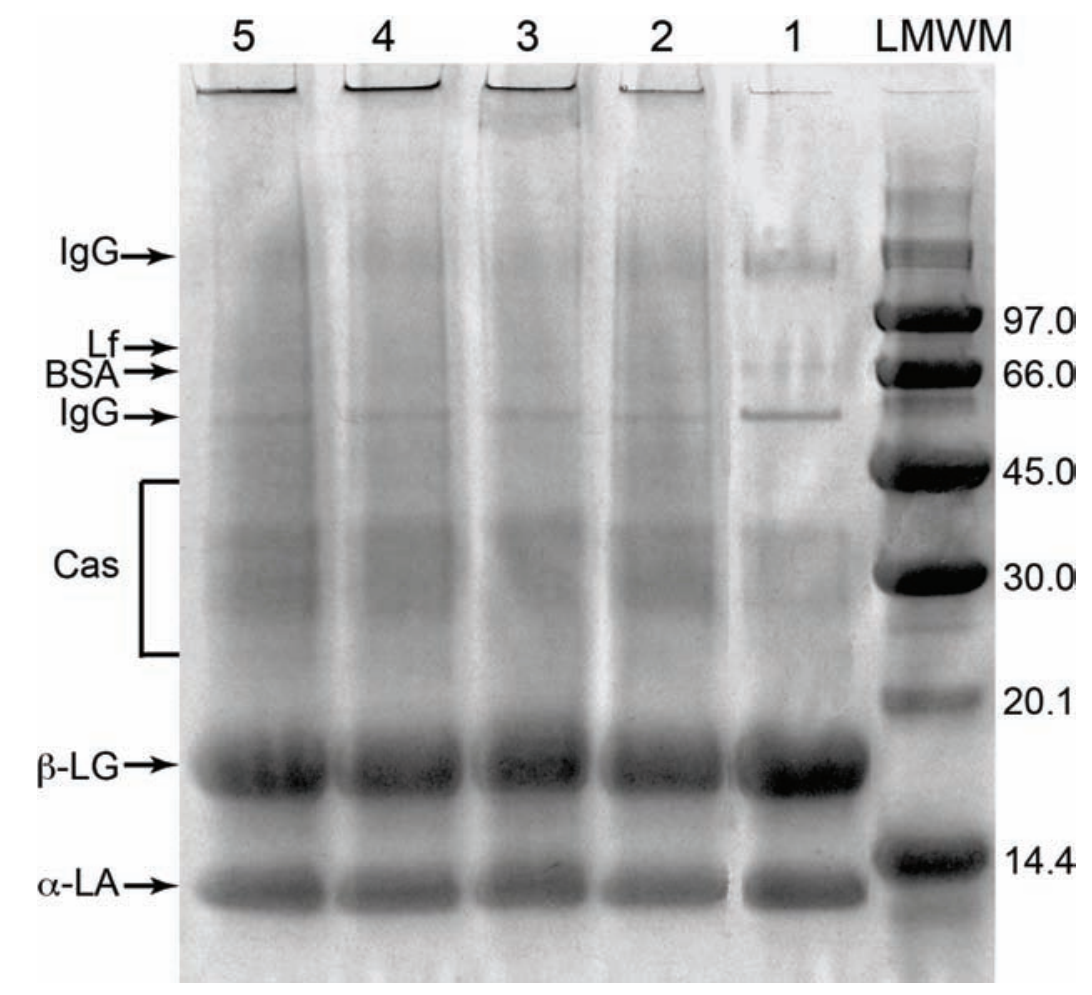


Figure 3B.

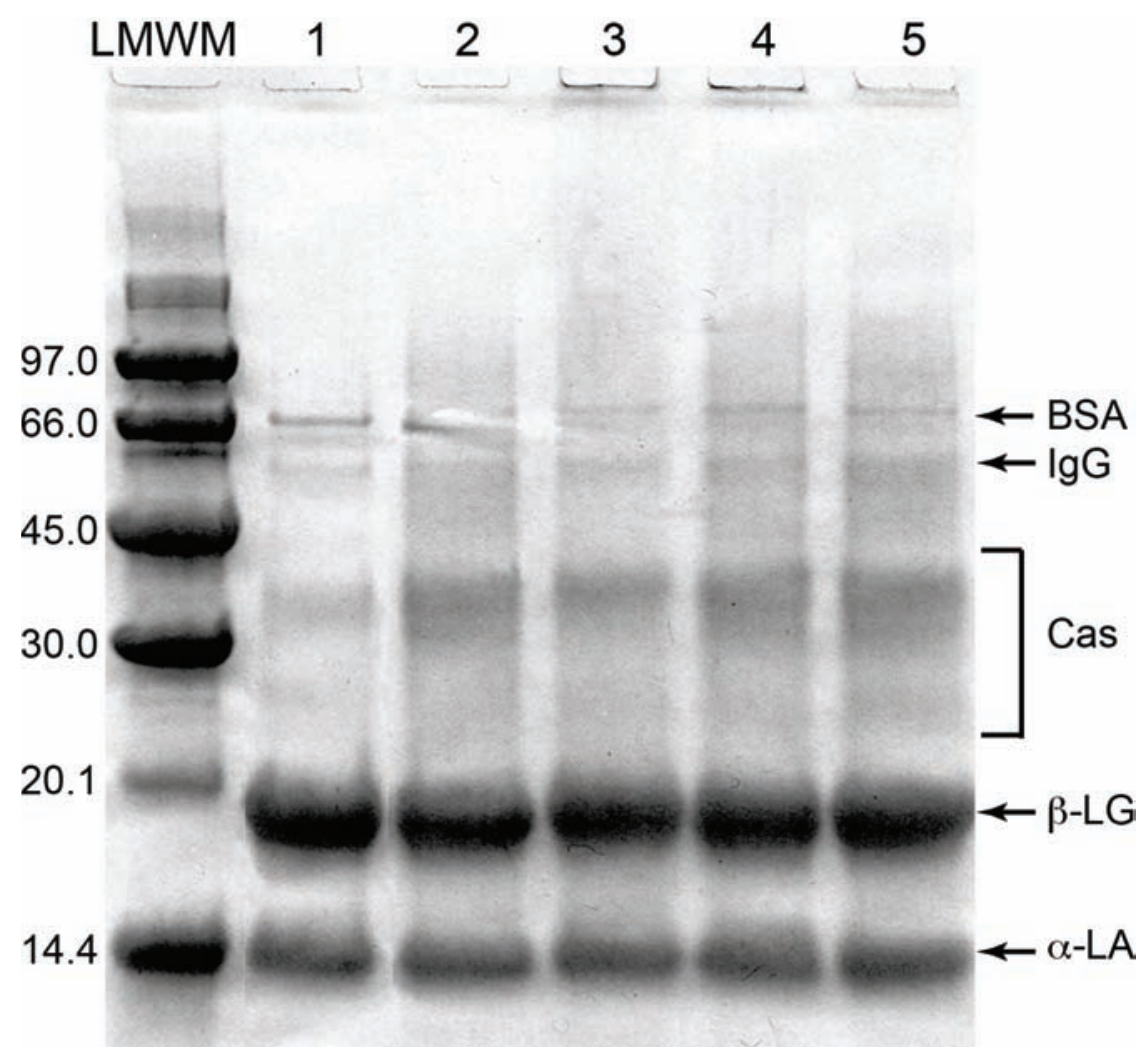


Figure 4A.

$$
-+7654321
$$


Figure 4B.

$-+7654321$ 
Figure 5.

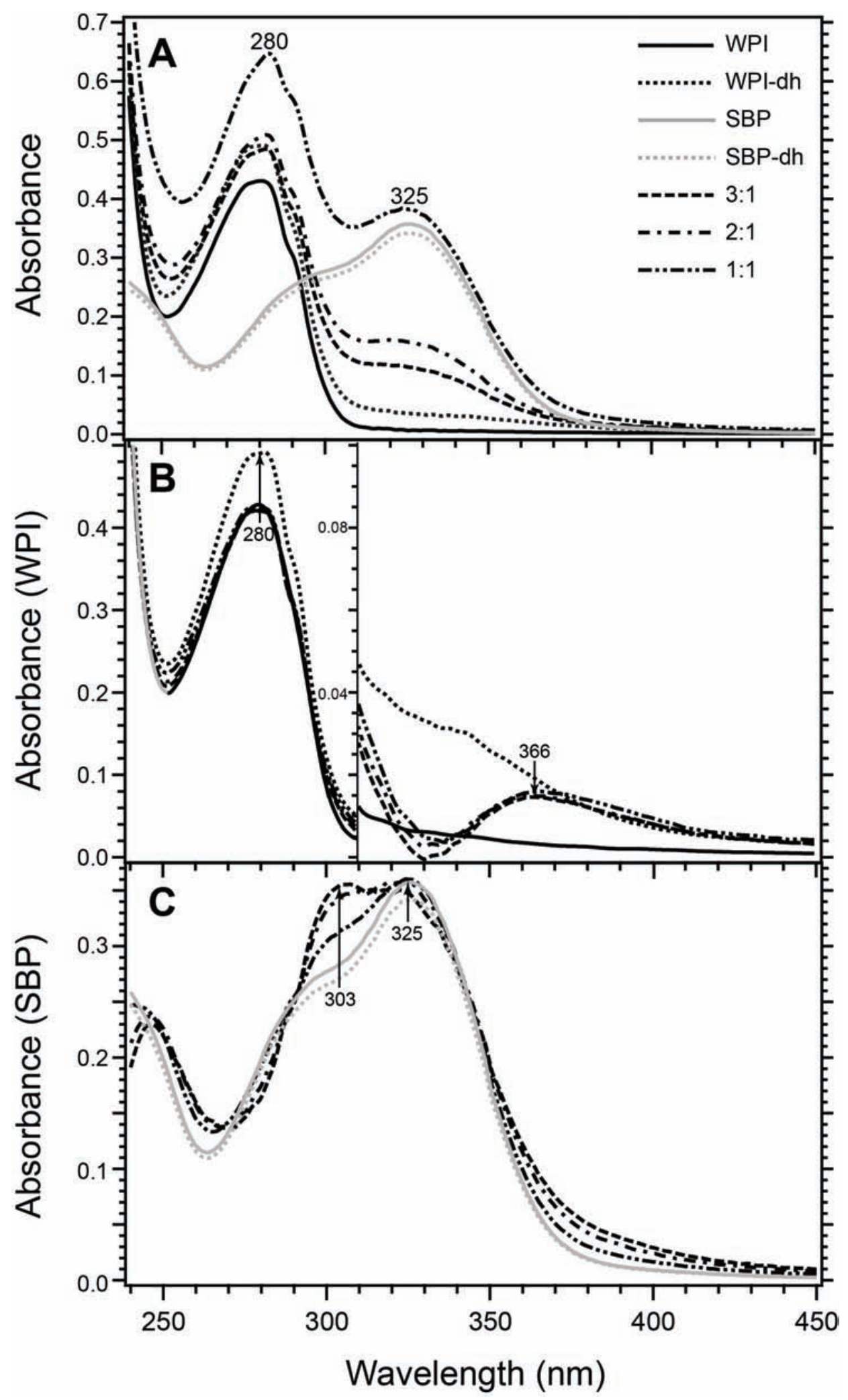


Figure 6.

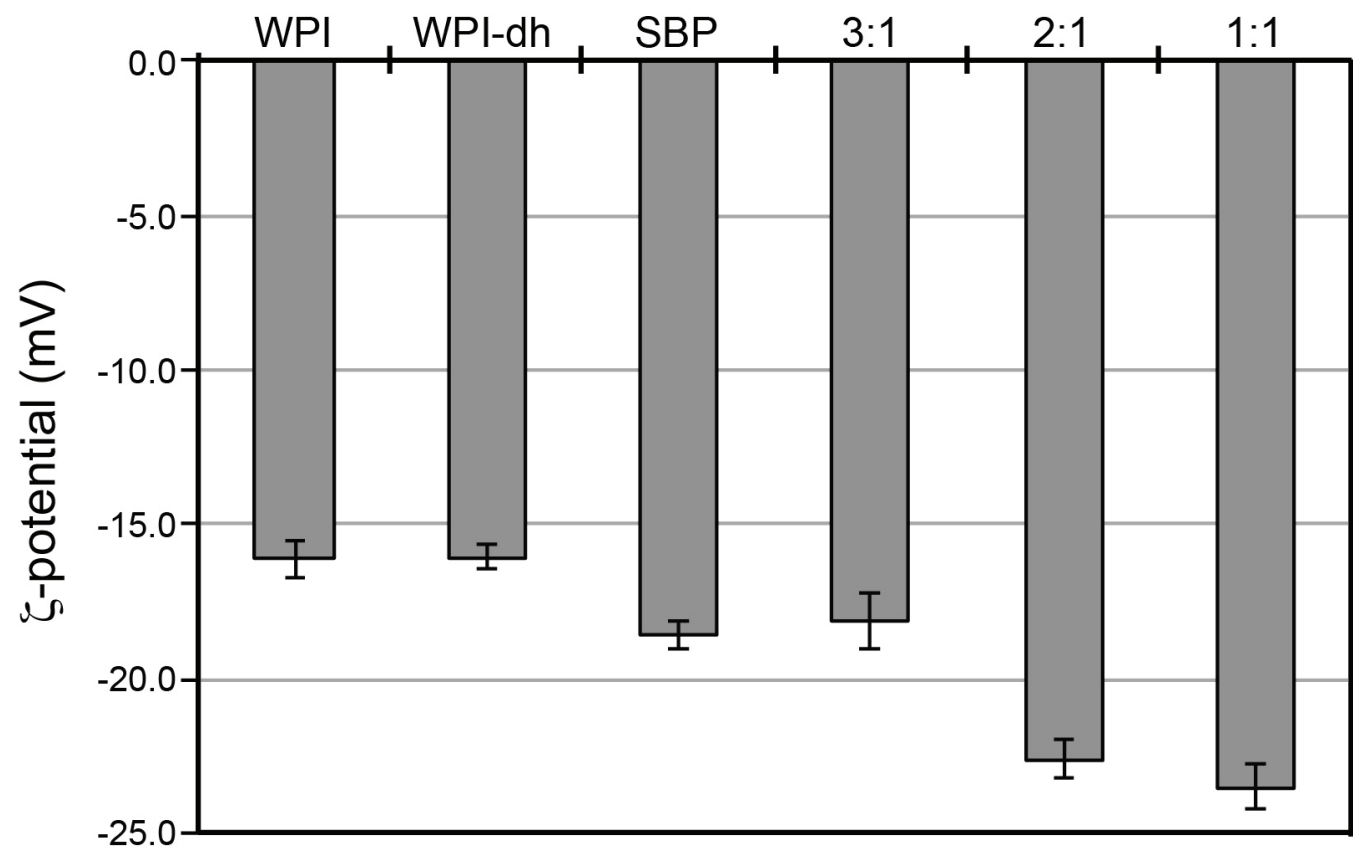


Figure 7.

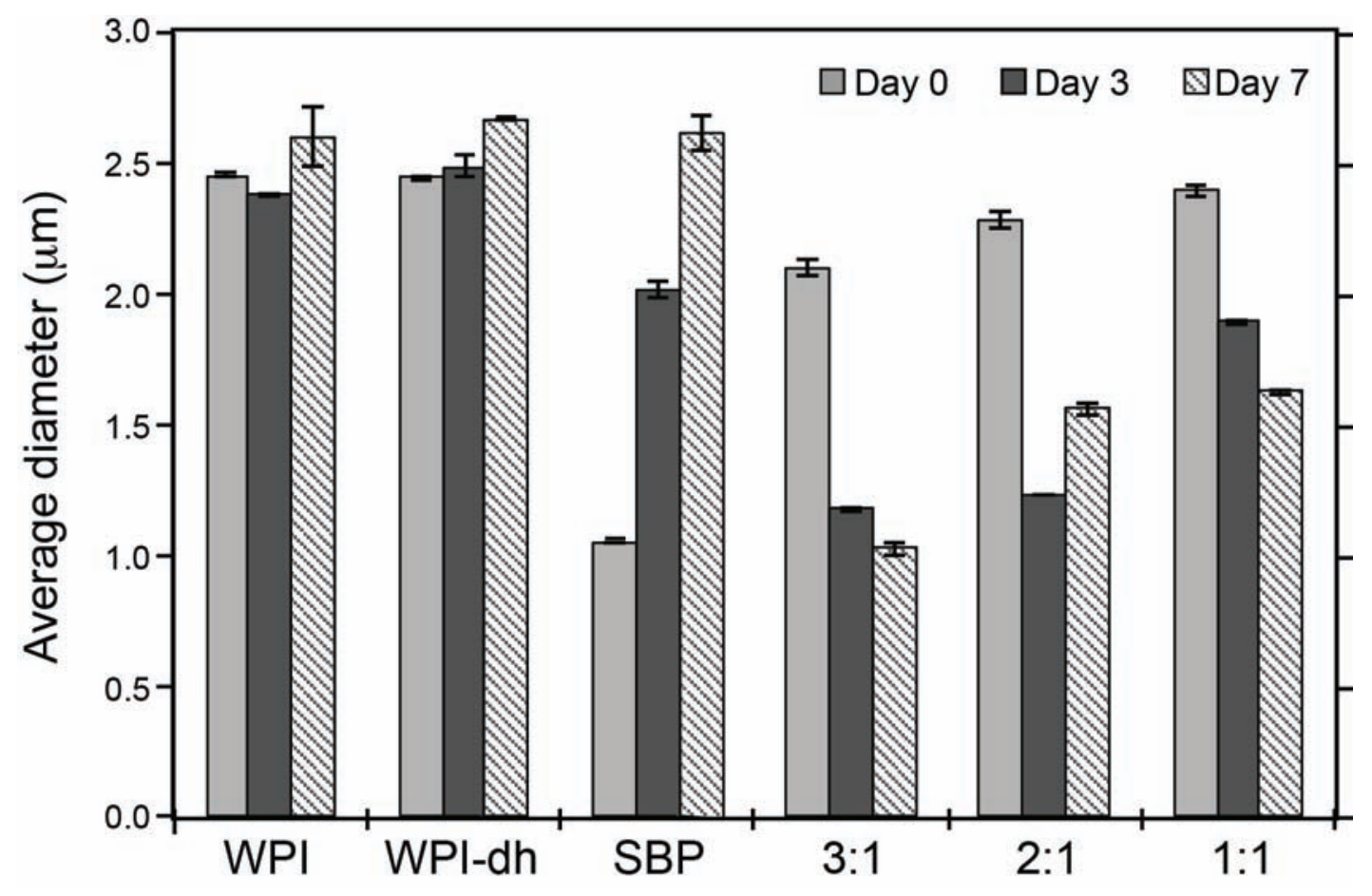

